Dharma Raflesia : Jurnal Ilmiah Pengembangan dan Penerapan IPTEKS 18 (1) 2020

\author{
PENGUATAN KELOMPOK REMAJA ISLAM MASJID \\ SEBAGAI UPAYA MENINGKATKAN KESEHATAN \\ REPRODUKSI REMAJA DI KOTA BENGKULU \\ STRENGTHENING OF ISLAMIC YOUTH ADOLESCENT \\ GROUPS AS AN EFFORT TO IMPROVE HEALTH \\ REPRODUCTION OF ADOLESCENTS IN BENGKULU CITY
}

\author{
Nurmukaromatis Saleha \\ Universitas Bengkulu \\ nsaleha@unib.ac.id \\ Rina Delfina \\ Universitas Bengkulu \\ Rdelfina@unib.ac.id \\ Maiyulis Abdurrohim \\ Universitas Bengkulu \\ Maiyulis@unib.ac.id
}

\begin{abstract}
This community service is held as a form of reinforcement for teenagers to realize Tegar youth. Tegar Teenagers are teenagers who avoid three reproductive health problems. These three problems are called the Youth Health Triad (KRR), namely Sexuality, Drug and HIV-AIDS. This activity was carried out on two Moslem Islamic Youth groups in Bengkulu City, namely Risma Nurul Ilmi and Risma Nurul Iman. The method used in the form of Communication, Information and Education (IEC) on the topic of the KRR Triad so as to produce an increase in adolescent knowledge which is assessed through pre and post tests of the level of adolescent knowledge. It is hoped that the follow-up of this activity can be a teenager agent of change to peers in overcoming the KRR Triad problem.
\end{abstract}

Keywords: KRR Triad, community empowerment, Risma 
Dharma Raflesia : Jurnal Ilmiah Pengembangan dan Penerapan IPTEKS 18 (1) 2020

\begin{abstract}
ABSTRAK
Pengabdian masyarakat ini diselenggarakan sebagai bentuk penguatan kepada remaja untuk mewujudkan remaja Tegar. Remaja Tegar adalah remaja yang terhindar dari tiga masalah kesehatan reproduksi. Tiga masalah ini disebut dengan Triad Kesehatan Remaja (KRR) yaitu Seksualitas, Napza dan HIV-AIDS. Kegiatan ini dilakukan pada dua kelompok Remaja Islam Masjid di Kota Bengkulu yaitu Risma Nurul Ilmi dan Risma Nurul Iman. Metode yang dilakukan berupa Komunikasi, Informasi dan Edukasi (KIE) tentang topik Triad KRR sehingga menghasilkan peningkatan pengetahuan remaja yang dinilai melalui pre dan post tes tingkat pengetahuan remaja. Tindak lanjut dari kegiatan ini diharapkan remaja dapat menjadi Agent of Change bagi teman sebaya dalam mengatasi masalah Triad KRR.

Kata Kunci: Triad KRR, pemberdayaan masyarakat, Risma
\end{abstract}

\title{
PENDAHULUAN
}

Tiga masalah Kesehatan Reproduksi Remaja merupakan faktor yang dapat mengganggu perkembangan fisik maupun psikologis remaja. Adapun tiga masalah tersebut adalah seksualitas, Napza dan HIV-AIDS. Berdasarkan data yang didapat dari Badan Pemberdayaan dan Perlindungan Anak Di Provinsi Bengkulu Tahun 2016 kekerasan seksual menempati angka tertinggi dari jenis kekerasan lainnya yaitu sebanyak 159 kasus atau 43\% (DPPP-KB Kab-Kota Bengkulu, 2017). Permasalahan lainnya terkait seksualitas remaja adalah pernikahan di bawah usia 20 tahun atau menikah di usia anak. Data yang didapat dari Badan Pusat Statistik (BPS) Provinsi Bengkulu pada Susenas 2017 menunjukkan 16,17\% perempuan menikah di bawah usia 16 tahun dan 23,04\% menikah diusia 17-18 tahun. Perkawinan usia anak juga memberikan dampak lainnya yang cukup besar diantaranya persoalan kesehatan yang dapat meningkatkan risiko angka kematian ibu (AKI) dan angka kematian bayi (AKB) serta memicu persoalan sosial dan ekonomi perempuan. Berbagai permasalahan lainnya yang dapat ditimbulkan pernikahan usia anak adalah meningkatnya angka KDRT, hak pendidikan anak, angka perceraian, serta stigma yang harus ditanggung oleh anak. 
Dharma Raflesia : Jurnal Ilmiah Pengembangan dan Penerapan IPTEKS 18 (1) 2020

Tabel 1.1

Tabel 8.2 Jumlah Korban Kekerasan Menurut Jenis Kekerasan

Di Provinsi Bengkulu Tahun 2016

\begin{tabular}{|c|c|c|c|c|c|c|c|c|}
\hline \multirow[b]{2}{*}{ No } & \multirow{2}{*}{ Kab/Kota } & \multicolumn{7}{|c|}{ Jenis Kekerasan } \\
\hline & & Fisik & Psikis & Seksual & Eksploitasi & Penelantaran & $\begin{array}{l}\text { Trafi } \\
\text { King }\end{array}$ & $\begin{array}{l}\text { Lain } \\
\text { Nya }\end{array}$ \\
\hline 1. & B. Selatan & 5 & 0 & 11 & 0 & 1 & 0 & 0 \\
\hline 2. & Rj. Lebong & 85 & 1 & 23 & 0 & 0 & 1 & 2 \\
\hline 3 & Bkl. Utara & 11 & 2 & 18 & 1 & 1 & 0 & 0 \\
\hline 4 & Kaur & 8 & 4 & 25 & 0 & 2 & 0 & 5 \\
\hline 5 & Seluma & 2 & 0 & 11 & 0 & 0 & 0 & 0 \\
\hline 6. & Mukomuko & 4 & 1 & 10 & 0 & 0 & 1 & 0 \\
\hline 7 & Lebong & 8 & 4 & 7 & 0 & 0 & 0 & 0 \\
\hline 8. & Kepahiang & 12 & 7 & 22 & 1 & 0 & 0 & 0 \\
\hline 9. & Bkl Tengah & 10 & 2 & 15 & 1 & 0 & 0 & 0 \\
\hline 10 & Kota Bkl & 13 & 10 & 17 & 0 & 2 & 1 & 1 \\
\hline & Jumlah & 158 & 31 & 159 & 3 & 6 & 3 & 8 \\
\hline
\end{tabular}

Sumber data : DPPP-KB Kab/Kota

Tabel 1.2

Tabel 8.4 Persentase Korban Kekerasan Menurut Jenis Kekerasan Di Provinsi Bengkulu Tahun 2016

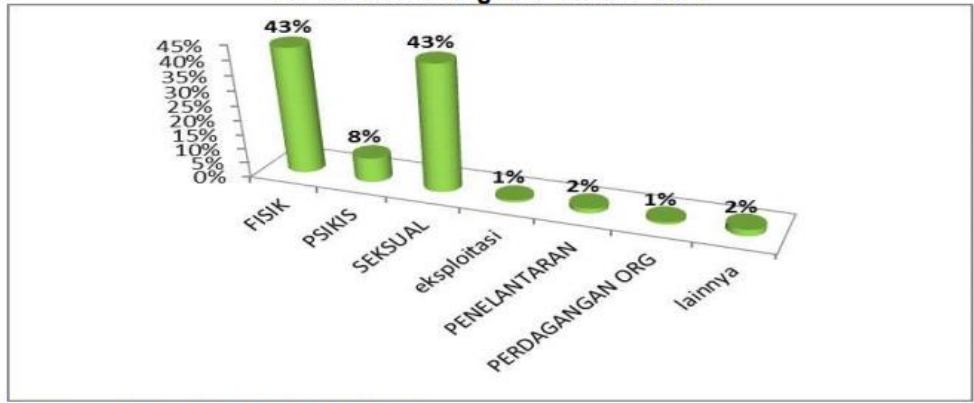

Sumber data : DPPP-KB Kab/Kota

Jenis kekerasan terhadap perempuan dan anak tertinggi adalah kekerasan fisik dan seksual, setiap korban dapat mengalami lebih dari satu jenis kekerasan. 
Dharma Raflesia : Jurnal Ilmiah Pengembangan dan Penerapan IPTEKS 18 (1) 2020

Untuk kasus Napza berdasarkan hasil Survei Penyalahgunaan Narkoba 2019 Badan Narkotika Nasional, Bengkulu merupakan salah satu provinsi dari lima belas provinsi dengan pemakai narkoba $100 \%$ berjenis kelamin laki-laki. Gambaran pemakaian narkoba di Kota Bengkulu berdasarkan Riset Kesehatan Dampak Penyalahgunaan Narkotika 2019 didapatkan estimasi orang yang pernah menggunakan narkoba di perkotaan adalah sebanyak 17.728 (90.00\%) dan mereka yang memakai narkoba dalam satu tahun terakhir adalah sebanyak $11.819(85,70 \%)$ (BNN, 2020). Angka tersebut melibatkan usia remaja di bawah usia 25 tahun. Kelompok pelajar dan mahasiswa merupakan kelompok yang sangat rentan terpapar narkoba.

Data yang didapatkan dari profil Kesehatan Dinas Kesehatan Provinsi Bengkulu tahun 2018, terdapat 1034 kasus HIV/AIDS 174 diantaranya telah meninggal dunia. Proporsi kelompok tertinggi pada rentang usai 25-49 tahun selanjutnya usia 20-24 tahun. Angka penderita HIV-AIDS di Kota Bengkulu sendiri berdasarkan Profil Kesehatan Kota Bengkulu tahun 2018 adalah 84 orang terdapat 1 penderita di rentang usia 4-14 tahun dan 9 orang penderita dengan rentang usia 2024 tahun atau usia remaja (Dinkes Provinsi Bengkulu, 2019).

Remaja adalah tahapan tumbuh kembang manusia yang dikenal sebagai masa transisi dari masa anak-anak ke masa dewasa. Tahapan ini dimulai dengan adanya pubertas dan berakhir setelah masuk dewasa. Pada masa ini terjadi maturasi biologik dan kepribadian disertai dengan gejolak emosi dan fisik yang tidak menentu (Wong, 2010; Bobak, Lowdermilk, Jensen, 2010). World Health Organitation (WHO) tahun 2014 mendefinisikan remaja adalah penduduk dalam rentang usia 10-19 tahun. Kementrian Kesehatan Republik Indonesia (Kemenkes RI) dalam peraturan menteri kesehatan No 25 tahun 2014 menyatakan bahwanya remaja adalah penduduk dalam rentang usia 10-18 tahun sementara itu Badan Kependudukan dan Keluarga Berencana (BKKBN) memberikan batasan rentang usia remaja antara 10 sampai dengan 24 tahun dan belum menikah.

Pada periode transisi dari masa anak-anak ke masa dewasa menyebabkan remaja rawan terhadap perilaku kesehatan yang menyimpang. Pendidikan kesehatan reproduksi pada setiap tahapan kehidupan menjadi sangat penting dilakukan. Afiyanti \& Pratiwi tahun 2017 menulis bahwa pendidikan seksualitas dan reproduksi penting bagi setiap individu dikarenakan keduanya dapat menjadi penentu status kesehatan secara umum (overall health) dan kualitas hidup (quality of life) individu. Dalam kenyataannya permasalahan seksualitas dapat menjadi penyebab langsung maupun tidak langsung dari kematian. Mengingat hal tersebut maka usaha promosi kesehatan reproduksi remaja penting untuk dilaksanakan. 
Dharma Raflesia : Jurnal Ilmiah Pengembangan dan Penerapan IPTEKS 18 (1) 2020

Orang tua masih menggangap tabu untuk memberikan pendidikan seksualitas, kondisi tersebut menyebabkan komunikasi yang tidak efektif antara orang tua dan remaja. Remaja akhirnya mendapatkan informasi tentang seksualitas dari sumber-sumber lain. Pentingnya komunikasi yang baik antara orang tua dan remaja guna meningkatkan upaya promosi kesehatan (Kusheta, Bancha, Habtu, Helamo, \& Yohannes, 2019).

Remaja yang berkelompok membentuk

Berdasarkan data tersebut maka diperlukan upaya preventif yang berkelanjutan. Upaya tersebut dapat menggunakan sumber potensi yang ada di masyarakat. Remaja bisa menjadi sumber kekuatan dalam mengatasi masalah mereka sendiri oleh karena itu pemberdayaan remaja sangatlah penting. Organisasi remaja dapat dijadikan sebagai agent of change untuk mengatasi masalah tersebut. Kelurahan Cempaka Permai khususnya di RT17, 18,19 dan 20 memiliki organisasi keremajaan yaitu Remaja Islam Masjid Nurul Ilmi. Risma ini aktif berkegiatan dalam rangka menyambut hari-hari besar keagamaan berupa penyelenggaraan lomba-lomba untuk anak-anak sekolah dasar. Namun kegiatan rutin yang bersifat internal anggotanya masih kurang bahkan boleh dikatakan tidak ada. Tim pengabdian masyarakat memandang Risma ini sebagai peluang dalam upaya preventif pencegahan Triad KRR. Kondisi serupa juga terjadi di kelurahan Penurunan tepatnya Risma Masjid Nurul Iman.

Kami menggunakan pendekatan teori keperawatan Nola. J Pender "Health Promotion Model" dalam pelaksanaan kegiatan pengabdian ini. Model ini menggabungkan 2 teori yaitu teori nilai harapan dan teori cognitif social yang konsisten dengan semua teori yang memandang pentingnya promosi kesehatan dan pencegahan penyakit adalah suatu yang hal logis dan ekonomis. Teori model promosi kesehatan (HPM) disintesis oleh Pender dari sumber keperawatan, psikologi, dan kesehatan masyarakat yang kemudian menjadi teori model perilaku sehat, khususnya pada sasaran dewasa dan dewasa muda (Khodaveisi, Omidi, Farokhi \& Soltanian, 2017). Pender mengemukakan konsep utama tentang faktor kognitif dan perseptual (mekanisme motivasional primer) yang meliputi Pentingnya Kesehatan, Persepsi Kendali Kesehatan, Persepsi Efektifitas Diri, Definisi Kesehatan, Persepsi Status Kesehatan, Persepsi Manfaat Perilaku, Persepsi hambatan terhadap perilaku promosi kesehatan maka dalam kegiatan ini kesehatan yang dimaksud adalah kesehatan reproduksi remaja. Kegiatan ini merupakan upaya preventif terkait Triad KRR terhadap anggota Risma pada kedua masjid ini. Potensi yang ada pada kelompok sasaran ini adalah berupa kesadaran mereka untuk berinteraksi 
Dharma Raflesia : Jurnal Ilmiah Pengembangan dan Penerapan IPTEKS 18 (1) 2020

sosial yang memungkinkan transfer ilmu dapat berjalan efektif. Kami tim berusaha membangun kembali semangat agar mereka kembali memiliki kegiatan-kegiatan positif. Khususnya dalam kegiatan ini diharapkan remaja memiliki peningkatan ilmu yang selanjutnya kesadaran diri untuk berperilaku sehat dan mampu menjadi agent of change bagi sesama remaja guna menanggulangi Triad KRR.

\section{METODE PENGABDIAN}

Metode kegiatan berupa Komunikasi, Informasi dan Edukasi tentang Kesehatan Reproduksi Remaja terutama yang berkaitan dengan Triad KRR (Seksualitas, Napza dan HIV-AIDS). Seksualitas adalah segala sesuatu yang menyangkut hidup manusia sebagai mahluk seksual, yaitu emosi, perasaan, kepribadian, sikap yang berkaitan dengan perilaku seksual, hubungan seksual dan orientasi seksual. Napza (narkotika, alkohol, psokotropika dan zat adiktif lainnya) adalah istilah lain dari Narkoba (narkotika, psikotropika dan zat berbahaya lainnya). Undang-Undang RI tahun 1997 tentang narkotika menyebutkan bahwa narkotika adalah zat atau obat yang berasal dari tanaman atau bukan tanaman baik sintetis maupun nnon sintetis yang dapat menyebabkan penurunan atau perubahan kesadaran, hilangnya rasa nyeri serta menimbulkan ketergantungan (Kemenkes RI, 2014). HIV adalah singkatan dari Human Immunodeficiency Virus yaitu virus yang melemahkan sistem kekebalan tubuh manusia. AIDS adalah singkatan dari Acquired Immuno Deficiency Syndrome, yaitu sekumpulan gejala yang timbul akibat melemahnya sistem kekebalan tubuh, karena terinfeksi virus HIV.

Kegiatan diawali dengan koordinasi dengan ketua Risma Masjid Nurul Ilmi Kelurahan Cempaka Permai dan Masjid Nurul Iman Kelurahan Penurunan. Kedua Ketua Risma ini menyambut baik rencana kegiatan karena mereka mengakui kegiatan mereka selama ini vakum dan monoton serta kurang tampak dukungan dari orang dewasa. Merekapun antusias dengan topik yang diangkat, karena banyak kejadian nyata disekitar mereka terkait tiga masalah tersebut. Perizinan dilakukan kepada Imam Masjid yang juga menyambut baik kegiatan ini. Kegiatan di Masjid Nurul Ilmi dilaksankan pada bulan September 2019 sedangkan di Masjid Nurul Iman pada tanggal 1 Maret 2020.

Pelaksanaan kegiatan inti berupa penyampaian materi edukasi Triad KRR. Kegiatan dilakukan di masjid masing-masing. Sebelum penyampaian materi tim melakukan pretest untuk mengukur pengetahuan awal sebelum edukasi yang kemudian akan dibandingkan dengan hasil post test. Penyampaian materi terdiri atas tiga sesi yaitu sesi materi Seksualitas, Napza serta HIV AIDS. 


\section{HASIL DAN PEMBAHASAN}
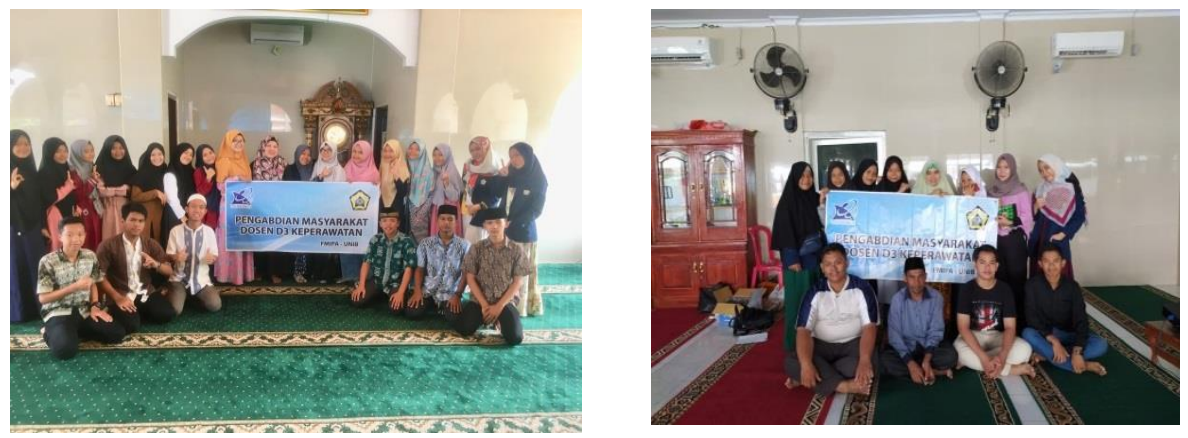

Gambar 1. Foto Bersama di masjid

a. Peningkatan Pengetahuan Remaja tentang kesehatan Reproduksi Remaja dan seksualitas di Kelurahan Cempaka Permai, b. Peningkatan Pengetahuan Remaja tentang kesehatan Reproduksi Remaja dan seksualitas di Kelurahan Penurunan di Kota Bengkulu

Materi seksualitas dipresentasi dengan menggunakan LCD serta Video. Peserta disuguhkan video tentang bahaya video porno yang bisa merusak jaringan otak terutama Pre Frontal Cortex (PFC). Pada sesi tanya jawab, antusias peserta sangat tinggi. Hal tersebut terlihat dari banyaknya pertanyaan yang muncul. Adapun pertanyaan yang diajukan berkisar masalah yang tengah viral yaitu "Apakah benar dengan berenang bersama seorang laki-laki di kolam yang sama bisa menyebabkan kehamilan?". "Bagaimanakah hukum kebiri bagi pelaku kejahatan seksual, sementara kita tahu seksualitas adalah hak setiap manusia?”. Untuk pertanyaan kehamilan di kolam renang tim menjelaskan bahwasanya hal tersebut telah dilkarifikasi oleh Ibu Sitti Hikmawatty komisioner KPAI bahwasanya pernyataan tersebut keliru. Tim menjelaskan bahwasanya sel sperma membutuhkan media untuk dapat hidup dan bergerak menuju sel telur milik perempuan. Air kolam bukanlah media yang dapat membuat sperma dapat bertahan hidup. Untuk pertanyaan hukum kebiri, di negara kita memang masih menjadi kontroversi. Permasalahan hukum kita serahkan kepada negara dalam mengaturnya. Yang utama dari kegiatan ini adalah bagaimana remaja dapat menjalankan tindakan antisipasi terhadap permasalahan seksualitas. Materi Napza disampaikan oleh Ns. Maiyulis, S.Kep., MPH. Ia menyampaikan mulai dari pengertian Napza, jenis-jenis Napza, tanda dan gejala orang yang mengalami adiksi, dampak dari penyalahgunaan Napza. Dalam penyampaian materi ini juga disampaikan kisah- 
Dharma Raflesia : Jurnal Ilmiah Pengembangan dan Penerapan IPTEKS 18 (1) 2020

kisah nyata yang terjadi pada beberapa remaja yang terkena dampak Napza. Penyampaian kisah nyata yang juga diambil dari tokoh-tokoh terkenal seperti selebritis tampaknya mempunyai kesan yang lebih efektif untuk menyampaikan pesan bahaya Napza kepada remaja.

Materi HIV AIDS Penyampaian materi visual tentang gambaran orang yang terkena HIV AIDS membuat peserta merasa ngeri terhadap bahaya HIV AIDS. Selain HIV AIDS juga disampaikan penyakit-penyakit menular seksual lainnya. Dalam sesi tanya jawab terlihat antusias peserta terhadap materi ini. Mereka lebih menyoroti stigma terhadap penderita HIV AIDS sebagai penyakit azab dikarenakan perbuatan seks terlarang. Disini tim kembali menanggapi dengan mengingatkan kembali cara-cara penularan HIV-AIDS selain melalui hubungan seksual juga bisa lewat jarum suntik yang dipakai bersama, juga transfusi darah. Berdasarkan hasil pre dan post test didapatkan $100 \%$ peserta mempunyai peningkatan pengetahuan terkait Triad KRR. Mereka dapat memahami bahwasanya kehamilan dapat saja terjadi dengan satu kali saja berhubungan seksual. Mereka dapat menjawab dengan tepat jenis-jenis Napza. Pengetahuan tentang cara penularan dan pencegahan terhadap HIV AIDS. Lalu melakukan sesi diskusi tanya jawab. Berdasarkan hasil kegiatan tersebut, remaja dapat mengekspresikan apa yang mereka rasakan. Mereka senang mempunyai media dan merasakan adanya pendampingan dari orang dewasa untuk mendapatkan informasi tentang kesehatan reproduksi dan kesehatan seksual mereka. Mereka senang karena selama ini merasa tabu dan malu berbicara tentang seksualitas, dengan adanya wadah ini membuat mereka merasa nyaman untuk bertanya dan menggali tentang seksualitas. Mereka menyatakan agar kegiatan ini dapat dijadikan agenda rutin.Berdasarkan hasil diskusi dengan peserta terkait rencana tindak lanjut maka disepakati kegiatan rutin penyuluhan kesehatan dari tim. Selain itu mereka ingin sekali memiliki wadah dimana mereka dapat berkreasi. Tim meggali apa saja potensi yang dimiliki oleh peserta. Beberapa peserta mengatakan mempunyai hobi menggambar, berdagang dan lain-lain. Hal ini memberikan ide kepada tim untuk menciptakan kegiatan remaja dimana mereka bisa menjadi Promotor Kesehatan Reproduksi Remaja sekaligus menyalurkan kreatifitas mereka. Tim berharap remaja yang memiliki hobi menggambar untuk dapat menciptakan gambar-gambar yang berisikan pesan-pesan KRR. Yang paling penting dari hasil kegiatan ini diharapkan remaja dapat mengaplikasikan gaya hidup sehat dalam kehidupan mereka sehari-hari demi menyongsong masa depan yang lebih baik. 
Dharma Raflesia : Jurnal Ilmiah Pengembangan dan Penerapan IPTEKS 18 (1) 2020

\section{SIMPULAN DAN SARAN}

\section{Simpulan}

Simpulan yang bisa diambil dari kegiatan pengabdian masyarakat ini adalah bahwa remaja memerlukan pendampingan orang dewasa untuk mendapatkan informasi-informasi sekitar kesehatan reproduksi remaja. Dari hasil evaluasi didapatkan peningkatan tingkat pengetahuan remaja tentang Triad KRR. Peserta memiliki kesadaran tentang bahaya Triad KRR. Peserta mengharapkan adanya kegiatan-kegiatan serupa seputar topik kesehatan. Mereka menyadari sebagai remaja mereka memiliki potensi yang dapat dimanfaatkan sebagai agent of change untuk mengatasi masalah-masalah yang ada di lingkungan. Penerapan teori HPM milik Pender efektif pengaruhnya dalam meningkatkan pengetahuan komunitas tentang kesehatan khusunya dalam kegiatan ini kesehatan kelompok remaja dalam komunitas.

\section{Saran}

Saran untuk ke depannya agar kita dapat mengoptimalkan potensi yang ada pada remaja. Remaja perlu diikutsertakan menjadi promotor kesehatan reproduksi remaja terutama pada teman sebaya. Penting juga untuk melakukan KIE kepada orang tua tentang komunikasi yang efektif dengan remaja. Saat remaja merasa nyaman dalam berkomunikasi maka ia akan terbuka kepada orang tua. Kedekatan antara remaja dengan orang tua dapat mencegah perilaku menyimpang kesehatan reproduksi. 
Dharma Raflesia : Jurnal Ilmiah Pengembangan dan Penerapan IPTEKS 18 (1) 2020

\section{DAFTAR PUSTAKA}

Afiyanti, Y., \& Pratiwi, A., (2017). Seksualitas Dan Kesehatan Reproduksi Perempuan. Promosi, Permasalahan dan Penanganan dalam Pelayanan Kesehatan dan Keperawatan. Depok, Indonesia: PT Rajagrafindo Persada,.

Badan Narkotika Nasional, Pusat Penelitian Data dan Informasi (2019). Riset Kesehatan Dampak Penyalahgunaan Narkotika 2019. (Puslidatin BNN). Retrieved from https://www.academia.edu/42097119/Riset_Kesehatan_Dampak_Penyal ahgunaan_Narkoba_2019

Badan Narkotika Nasional, Pusat Penelitian Data dan Informasi (2020). Survei Prevalensi Penyalahgunaan Narkoba 2019. (Puslidatin BNN). Retrieved from https://puslitdatin.bnn.go.id/berita/

Dinas Kesehatan Provinsi Bengkulu, (2019). Profil Kesehatan Provinsi Bengkulu tahun 2018. Bengkulu, Indonesia.

Dinas Pengendalian Penduduk dan Keluarga Berencana (DPPKB) Provinsi Bengkulu. (2018).

Khodaveisi, M., PhD, Omidi, A., Ms, Farokhi, S., Ms, \& Soltanian, A. R., PhD (2017). The Effect of Pender's Health Promotion Model in Improving the Nutritional Behavior of Overweight and Obese Women. International journal of community based nursing and midwifery, 5(2), 165-174.

Kusheta, S., Bancha, B., Habtu, Y., Helamo, D., \& Yohannes, S. (2019). Adolescent-parent communication on sexual and reproductive health issues and its factors among secondary and preparatory school students in Hadiya Zone, Southern Ethiopia: institution based cross sectional study. BMC pediatrics, 19(1), 9. https://doi.org/10.1186/s12887-018-1388-0

Wong D. L.,Whaly (2010). Buku Ajar Keperawatan Pediatrik, Alih bahasa Sunarno,Agus dkk.Edisi 6 Volume 1.Jakarta :EGC. 